\title{
On the Conceptual Basis of the English Adjectival Category
}

\author{
Marina Antonova \\ National Research University Higher School of Economics
}

\begin{abstract}
Correspondence concerning this article should be addressed to Marina Antonova, National Research University Higher School of Economics, Malaya Pionerskaya, 12, Moscow, Russian Federation, 115054.

E-mail: mbantonova@hse.ru
\end{abstract}

\begin{abstract}
The paper focuses on the cognitive foundation of English adjectives that denote mental characteristics of human beings. Several cognitive models have been advanced in an attempt to account for the semantic structure underlying the lexical category in question. After reviewing these models, a method for determining which of them most accurately captures the "cognitive reality" of English adjectival "deep structure" is proposed. The paper concludes with arguments for the inclusion of additional "motion attributes" to Lakoff's ICM (1987), namely, "guide's support" and "speed".
\end{abstract}

Keywords: lexical category, conceptual base, cognitive model, metaphoric concept, image schema, archetypical concept

Relatively recently, a number of language phenomena and issues have been reinterpreted from the perspective of cognitive linguistics. Particularly noteworthy are the developmental genesis of new meanings by words (Vendler, 1967; Lakoff, 1987, pp. 416-46; Belyaevskaya, 1992), the cognitive associations behind metaphors (Jonson \& Lakoff, 1980; Zyikova, 2014) and psychological motifs for creating synonyms (Porohnitskaya, 2014), to name but a few. Cognitive linguistics has also made inroads into language teaching, enabling learners to understand the reasons for selecting one word over another in a particular communicative context through explanation of their conceptual grounds. To more accurately and fully understand a speaker's communicative intentions, it is necessary to glean the "deep" structure, or concept, underlying a word's "surface" characteristics (Chomsky, 1965, pp. 64-67; Lakoff, 1987, pp. 311-312; Croft \& Cruse, 2004, p. 30). Otherwise, learners end up grasping just a tiny fraction of a word or phrase's meaning, at times totally misunderstanding it. Language learners should be encouraged to decipher the deep, conceptual meaning conveyed by lexical units and make connections between the outer form of the word and its conceptual basis.

The aim of the present research is to ascertain the principles underlying human categorization of "quality" in English, in particular, the categorization of mental characteristics via adjectives. The following hypothesis is advanced: The conceptual basis of the adjectival category is formed by archetypical conceptions/ideas specified by certain cognitive models. In this study, the category includes 400 adjectives of varying word structure, namely, simple, derived and compound words.

"Parole" formation resulting in "langue" formation is closely connected with the processes of conceptualization and categorization of real-world objects, events and phenomena. In his monograph on language origin, Jespersen argues that man is naturally predisposed to classification, that he "is a classifying animal" and "the process of speaking is nothing but distributing phenomena, of which no two are alike in every respect, into different classes on the strength of perceived similarities and dissimilarities" (Jespersen, 1922, pp. 387-388).

In the same vein, Lakoff claims that the ability to categorize is a distinguishing feature of a human being's mind, perception, action and speech. Without it people could not function in the physical world let alone their social and intellectual lives since "any time we produce or understand any utterance... we are employing dozens if not hundreds of categories: categories of speech sounds, of words, of phrases and clauses, as well as conceptual categories" (Lakoff, 1987, pp. 5-6). The bulk of the empirical research 
indicates that the process of categorization is largely automatic and unconscious. This, in turn, often leads to the illusion that we categorize things "as they are, that things come in natural kinds and that our categories of mind naturally fit the kinds of things there are in the world" (Lakoff, 1987, p. 6). However, categorization is the result of implicit reasoning that unwittingly gives rise to subjective worldviews quite removed from "reality". From this it is clear why investigating categories is imperative, as elucidation of its mechanisms will enable a better understanding of the way in which people think about and interpret the world.

Lakoff argues that any process of categorization is guided by idealized cognitive models (ICMs) which organize our knowledge, with category structures cognitive by-products. With respect to structuring principles, four kinds of ICMs - likened to "gestalts" have been identified: image schematic, propositional, metaphoric and metonymic (Lakoff, 1987, p. 68, p.154). As we shall see, the category of adjectives denoting mental properties is structured by image schematic and metaphorical cognitive models.

\section{Materials and Methods}

\section{Conceptualization of the Ontological Category of Property though Adjectives}

Being a biological species, people demonstrate universal and natural mind archetypes, or common ways of reasoning about the world (Mann, 1960, p. 175; Jung, 2005). So, alongside apparent differences there exist some universal principles of categorization to which typological research testifies, for instance, that of Denny (in Lakoff, 1987, pp. 112-113). The major conceptual categories are considered to be seven ontological categories, or so-called conceptual "parts of speech": Thing, Event, State, Place, Path, Property and Amount. What is more, the mapping between conceptual and syntactic categories is manyto-many (Jackendoff, 1992, p. 34). Concerning English, the ontological category of Property is represented by adjectives, in particular.

It should be mentioned, and not in passing, that conceptualization of property (or quality) via adjectives does not occur simultaneously with speaking genesis. Adjectives as a part of speech appear well after the formation of cardinal ones. Part of speech evolution commences with the substantive and then proceeds to the verb and finally to the adjective (Kubryakova, 2008, p. 39). The assumption that the property categories of verb and adjective arise from the substance category as a result of distinguishing between an entity (thing) and its constituents (properties) is justified by the fact that a child acquires the names of things before the names of their properties (Kubryakova, 2004, p. 253-270). This affects directly the formation of the adjectival category conceptual base in the English language.

The category chosen for this study includes mental property adjectives which denote one of the characteristics verbalized in the first place. While analyzing an array of the ergative languages (African, Australian and the languages of American Indians), R. Dixon registered in closed, small and thus estimated groups of adjectives the nominations of human mental characteristics, namely, stupid, foolish, clever, intelligent, wise. As the researcher persuasively argues that "only significant qualities have names" (Dixon, 1982, p. 50), we can conclude that intellectual capabilities belong to basic human characteristics. In English, the category of mental property adjectives can be traced back to the Old English period.

Intellectual activities regulate and determine all other kinds of activities - physical, theoretical and artistic practices as well as communication and behaviour. Therefore, a person possesses several types of knowledge: scientific, practical, religious, artistic, rational, irrational, personal, etc. (SFS, 2004, p. 241). As a person naturally finds himself in one or another community, he inevitably becomes involved in some form of communication. Subconscious estimation and evaluation of the intellectual abilities of one's interlocutor for the purpose of achieving a particular interaction is part and parcel of any communication. In fact, intellectual abilities play such a significant role that they compelled Chafe to single out, among the basic processes of verbalization, those dealing with the speaker's estimation of both the addressee's mind state at the current moment and its operational abilities within a certain communicative act (Cheyf, 1983, pp. 38-39).

\section{Results}

\section{Peculiarities of the Lexical Category "Mental Characteristics of Human Beings" Represented by English Adjectives}

Since cognitive linguistics, in contrast to classical theory of categorization, acknowledges various kinds of category structure, it is necessary to determine which kind of category the adjectival category in question belongs to. It is a lexical category; that is, a category that reflects the world's ontology, or our encyclopedic, extra-linguistic knowledge about natural objects, phenomena and their qualities. Boldyrev notes that in such categories, words are grouped together not according to their language 
features but on the grounds of logical inclusion into the same category of objects denoted by them. Lexical categories rest on the invariant-variant principle, which implies comparison with the invariant and identification of the invariant features replicated in every variant (Boldyirev, 2009, pp. 29-31). Given that they are logical, or abstract, constructions, they should not be considered as language categories in the strict sense. Rather, they are language analogues of categories that include natural objects and objects of man's inner world, thereby realizing the gnoseological language function (Kolshanskiy, 1976, p. 22; Boldyirev, 2012, pp. 56-61).

Lexical categories are deprived of prototypical effects, as the existence of the most typical (or prototypical) lexeme to express some lexical meaning is hardly possible (Boldyirev, 2013, p. 7).

In addition, it is claimed in the present research that another peculiarity of the mental property adjectival category is that its referential points and boundary emerge within a certain context. It was Croft and Cruse who first described such categories (Croft \& Cruse, 2004, p. 89, pp. 93-95) when citing Lakoff's example of the graded category tall man (Lakoff, 1987, p. 56). The quality denoted by mental property adjectives can in no way be perceived, as it manifests itself in manner of behaviour, speaking, works, etc. (i.e., in the products of human activities). When a speaker names someone as clever, aware and sagacious or, vise-versa, stupid and unaware, the judgment, in fact, refers to the manifestation of knowledge restricted to a specific communicative situation and specific participants. Things considered to be achievements for a child and motivate calling him clever are never viewed this way when applied to a grown-up. Every individual's intellectual abilities are unique and are first estimated according to his own scale and second according to other people's scale. Moreover, estimated knowledge covers only certain contextually determined fields. For instance, we can estimate a person's gifts, common sense, life experience, skills, etc. It goes without saying that a person can be a true professional in possession of extraordinary knowledge in a certain field, and, at the same time, demonstrate profound ignorance as far as other fields of knowledge are concerned. So, the characteristics clever/stupid are quite subjective with respect to an individual's intellectual activity, lending support to the notion that the reference points and boundary of this adjectival category are context dependent.

\section{Factors Influencing the Conceptual Base of the Adjectival Category}

It is argued in this research that this category's conceptual base is influenced by two factors. Firstly, the adjectives denote an abstract, unperceived property: mind's activity cannot be seen or touched or tested with the help of sensory organs. This lexical category is of particular interest in this respect. To describe abstract ideas, a human being employs metaphors as they help our mind understand "something difficult for cognition, something invisible, concealed, hard to understand" (Nikitin, 1996, p. 253). At the pre-logical syncretic reasoning stage, there prevails not classifying but metaphorical (analogous, associative) ways of comprehending things (Nikitin, 2003, p. 50). Even primitive poetry and oratorical prose used metaphors (Meletinskiy, 1998, p. 64). Taken together, studies on the way people categorize suggest that reasoning is embodied and imagination and human categorization are essentially a matter of both human experience (perception, motor activity, culture) and imagination (metaphor, mental imagery) (Lakoff, 1987, p. xvii, p. 8).

Another peculiarity of human reasoning that affects the quality of conceptualization is the systematization of real world data as polar opposites. Foreign and Russian scholars have observed similar antinomies in all archaic cultures, which has led to the conclusion that they rest on universal ground (C. Lévi-Strauss, V. V. Ivanov, V. N. Toporov, E. M. Meletinskiy, etc.). The universal, semantic ground underlying all binary classifications created by humans are ubiquitous abounding in natural languages and in mythology. Meletinsky distinguished and meticulously analyzed numerous elementary semantic opposites and found that they correspond to initial space positioning and sensory perception (up/down, in/out, left/right, light/ dark, far/close, etc.). These opposites are "objectified" and complemented by elementary correlations in cosmic space and time continuums (sky/earth, land/ sea, sun/moon, winter/summer, north/south, etc.) and in social life (friend/foe, male/female, old/young, etc.). Further, one element of each oppositional pair is marked as positive while the other is marked as negative.

Meletinsky claims a direct linkage between distinguishing contrasting properties or features and separate things. We become aware of various objects of perception thanks to the contrast in their perceived qualities, and thus we can expose objects to elementary analysis and classification (Meletinsky, 1976, p. 231). The ability to contrast perceived qualities is unique to human world cognition: the mind singles out not an isolated quality on its own but one against the background of contrasting qualities. In the end, only opposing features are distinguished and denoted by means of language.

It is noteworthy that while enumerating lexical prototypes for each part of speech, Wierzbicka suggests semantically opposed concepts only for the adjectival category. For the verb category, for instance, separate 
yet not polar items are given: see, say, hear, etc. Universal lexical adjectival prototypes are considered to be words with the meaning BIG and SMALL, GOOD and $\mathrm{BAD}$, with the former pair serving as the best example (Vezhbitskaya, 2011, pp. 230-231). There is no doubt that these antinomies are evidence that the function of inherent adjectives is to denote contrasting features. As for adjectives denoting mental properties, they also demonstrate contrasting relations en route to forming binary semantic opposites, which can be conditionally labeled as "clever/stupid".

Here a question arises: how can archetypical opposites that form the conceptual basis of the adjectival category be unearthed? The present research has demonstrated that they can be revealed through the etymological analysis of words; that is, by observing the "life of a word" and its semantic changes in the course of language system development. Etymological data can help clarify which idea a name rests on. Kubrykova notes that several etymological studies have established that at early stages of language formation the relationship between the world of things and the world of words was more direct, more immediate and even more apparent (Kubrykova, 2008, p. 19).

\section{Discussion}

\section{Cognitive Models Underlying the Semantics of the English Adjectival Category}

Taken together, the two aforementioned factors have influenced the interpretation and denotation of human intellectual properties. Let us justify this view with examples, beginning with metaphorical cognitive models.

As the research has shown, one cognitive motif of the adjectives under investigation is the conception of light and dark, of visible and indiscernible. Associations of reason and knowledge with light on the one hand and of stupidity and ignorance with darkness on the other, is universal. The source domains of metaphorical idealized cognitive models are archetypical conceptions LIGHT and DARKNESS, which form one of the fundamental antinomies. In fact, Pythagorians included it in their Table of Opposites. It has been distinguished by the mind on the strength of a primitive sensory perception (Meletinskiy, 1998, p. 230), namely, the visual one. In the human mind, there has developed an inextricable cause-and-effect relationship between the physical ability to see and knowledge acquisition. The logical sequence "to see, hence to know" is reflected in words originating from the Pre-Indo-European stem "weid-/wid- "to see" in the meaning of the Old English preterite-present verb witan (later - wit "to know"), which literally meant "I have seen, hence, I know"; in the meaning of the adjective wise and the noun wit (in Old English usually gewit) (OED).

According to folk experiential knowledge, a person having good sight is able to discern far-away obstacles and dangerous things on his path and thus try to avoid them. Moreover, a human is thought to be capable of seeing not only with the help of a special body organ the eyes, but also with the help of mental sight, which enables us "to discern" forthcoming consequences of various actions, to be aware of what is likely to happen, otherwise saying to foresee. And foresight, prudence, has always been appreciated and regarded as a merit. The conceptual bases of the adjectives farsighted $(1641)^{1}$ far-seeing (1837) are composed of the elementary conceptions "far" and "light" since both the verb see and the noun sight originates from the

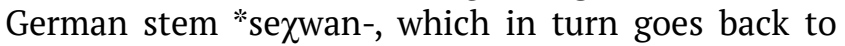
the Indo-European "seq- "to see". Given that humans possess mental sight, it is supposed that there exist mental eyes, so to speak: far-eyed (1903). Keeping these eyes open, one can adequately comprehend and estimate the received information: open-eyed (1648) "having the mental 'eyes' open" (OED).

Another type of cognitive model which guides adjectival category structure is image schemas. Here, mental activity is understood in terms of a kinesthetic source-path-goal schema.

The conception of motion is archetypical, recognized since the dawn of human existence. The importance and essential character of this conception can be justified by the fact that Pythagorians' Table of Opposites contains the antinomy "rest/motion" (Podosinov, 1999, p. 501).

Lakoff points out the following elements of its structure: a source (starting point), a destination (end point), a path (a sequence of contiguous locations connecting the source and the destination) and a direction (toward the destination) (Lakoff, 1987, p. 275). Knowledge and good reasoning are associated with these structural elements. For example, choosing the only right path implies certain knowledge: the adjective learned (XIV c.) originates from the ProtoGermanic *liznojan "to follow or find the track", derived from the Pre-Indo-European stem *leis- "track". On the contrary, motion along an unfamiliar, wrong path indicates ignorance, unawareness: unlearned, clueless. The etymon of the word clueless (1862) is the native English noun clew (the phonic variant is clue) meaning "ball of thread", "yarn". In the Middle English period, clue developed a metaphorical sense of "that which points the way" due to the myth about Theseus.

\footnotetext{
${ }^{1}$ In the brackets the year when the word was firstly registered is given.
} 
Reaching the destination quickly and successfully is possible only if the right direction and trajectory have been chosen while moving along a closed looped path. Inability to understand something, to comprehend information, to make a decision is associated with circular motion. An individual's reason proceeds as if along a circuit: an informal adjective "loopy" (1925), meaning "mad or silly", is a derivative of the noun loop.

Reason and knowledge are associated with translational or upward motion, which also symbolize knowledge obtaining an advanced stage of development and progress. Conversely, stupidity and the inability to obtain knowledge are associated with reverse motion, or regress: resourceful/unresourceful originate from the Latin verb surgere "to rise, spring up"; proficient goes back to the Latin verb proficio "to make progress, go forward"; backward is derived from the word aback "backwards, behind", which is Germanic in origin.

In my view, aside from the constituents Lakoff has detailed, other attributes of motion comprise the source-path-goal schema, namely, the guide's support and speed. The participation of these ideas in the conceptual basis of the category can be exemplified by the following adjectives: educated, uneducated, untrained and sagacious. The more aware of the path a person is, the easier it is to successfully proceed to the goal. That is why, in some cases, the aid of a competent guide is needed: the adjective educated (XVc.) originates from the Latin verb educare, which is a frequentative of educere "bring out, lead forth", from ex- "out" and ducere "to lead". Travelling alone, unguided, a person can lose his way or take the wrong path: uneducated, untrained from the Pre-Indo-European stem *tragh"to pull, to draw". However, a traveler can also seek and achieve the goal on his own: sagacious relates to PreIndo-European stem "sag- "to track down, trace, seek".

As for the conception of speed, my findings have shown that reason and knowledge are associated with high speed, while slow motion or cessation of motion are interpreted as stupidity: slow originates from the corresponding Old English adjective and conveys the sense "inactive, sluggish"; stupid can be traced back to the Latin verb stupere "to stop, be motionless, be stunned". The relationship between speed and cleverness is rooted in ontological knowledge, as "people's ideas about characteristic features of real animals have comprised zoomorphic codes" (Toporov, 1992, p. 441). This notion finds support in the fact that images of some animals have become conventional symbols of certain human behaviours, traits and character. For instance, an ass and a cow are considered to be etalons for slow-mindedness and stupidity, and a person likened to these animals typically ignores other people's explanations and guidance. Related zoonyms motivate the following adjectives: bovine (XIX c.) is derived from the Latin noun bos, bov- "ox, cow"; asinine (XV c.) "extremely stupid or foolish" originates from the Latin adjective asininus "stupid", derived from the noun asinus "ass", which in Latin also meant "dolt, blockhead".

Interestingly, a clever, quick-thinking person can be presented as the personification of a creature capable of fast motion: British slang adjective fly (XIX c.) "clever, keen, ingenious" originate from the Old English fleoge "a flying insect".

All in all, the ICM image schema - the kinesthetic source-path-goal schema - comprises the following human mental property adjectival opposites: awareness/unawareness of the path, presence/absence of a guide, awareness/unawareness of the direction and high/low/zero speed of motion.

Observe, however, that semantics of an adjective can depend on more than one ICM. Let us take, as an example, the informal word batty (1907), which originates from the idiom bats in one's belfry. The conceptual basis of the adjective combines a kinesthetic schema, which conveys the idea of chaotic motion without a goal, direction, or path, and a metaphoric ICM, which instills the idea of darkness, hindering achievement of the goal and evoking a feeling of helplessness. Hendrickson notes that "the image of bats flapping their wings and squeaking in the dark is a strong one that does suggest craziness" (Hendrickson, 2008, p. 65).

\section{Conclusion}

In conclusion, it should be emphasized that the analysis of deep, conceptual structures underlying the semantics of English adjectives may afford us a precious glimpse of the conceptual basis of the category. This, in turn, would open the door to its comparison with that of other languages - for instance, Russian, with untold implications and applications for the language teaching process.

\section{References}

Azarenko, S. A. (Ed.) (2004). Sovremennyiy filosofskiy slovar [Modern philosophical dictionary]. Moscow, Russia: Akad. proekt.

Barnhart dictionary of English etymology. (1988). New York, NY: The H. W. Wilson Company.

Belyaevskaya, E. G. (1992). Semanticheskaya struktura slova $v$ nominativnom $i$ kommunikativnom aspektah [The semantic structure of the word in the nominative and communicative aspects]. Moscow, Russia: MGLU. 
Boldyirev, N. N. (2009). Problemyi issledovaniya yazyikovogo znaniya [Problems of research of language knowledge]. Kognitivnyie Issledovaniya Yazyika. Kontseptualnyiy Analiz Yazyika, 1, 91-103.

Boldyirev, N. N. (2012). Kategorialnaya sistema yazyika [Categorical language system]. Kognitivnyie Issledovaniya Yazyika. Kategorizatsiya Mira $v$ Yazyike, 10, 17-120.

Boldyirev, N. N. (2013). Aktualnyie zadachi kognitivnoy lingvistiki na sovremennom etape [Actual problems of cognitive linguistics at the present stage]. Voprosyi Kognitivnoy Lingvistiki, 1, 5-13.

Cheyf, U. L. (1983). Pamyat i verbalizatsiya proshlogo opyita [Memory and verbalization of past experience]. Novoe $v$ Zarubezhnoy Lingvistike: Prikladnaya Lingvistika, XII, 35-73.

Chomsky, N. (1965). Aspects of the theory of syntax. Cambridge, MA: The MIT Press.

Croft, W., \& Cruse, D. (2004). Cognitive linguistics. Cambridge, UK: Cambridge University Press.

Dixon, R. M. W. (1982). Where have all the adjectives gone? Berlin, Germany: Mouton Publishers.

Hendrikson, R. (2008). The facts on file encyclopedia of word and phrase origins (4th ed.). New York, NY: Facts on File.

Jackendoff, R. (1992). Languages of the mind: Essays on mental representation. Cambridge, MA: Massachusetts Institute of Technology.

Jespersen, O. (1922). Language: Its nature, development and origin. New York, NY: Henry Holt \& Co.

Jung, K. G. (2005). Psihologicheskiy kommentariy $\mathrm{k}$ «Tibetskoy knige mertvyih» [Psychological commentary on the "Tibetan Book of the Dead"]. Tibetskaya kniga mertvyih (pp. 3-18). Moscow, Russia: Eksmo.

Kolshanskiy, G. V. (1976). Nekotoryie voprosyi semantiki yazyika $\mathrm{v}$ gnoseologicheskom aspekte [Some questions of semantics in the epistemological aspect]. In Printsipyi $i$ metodyi semanticheskih issledovaniy (pp. 5-31). Moscow, USSR: Akad. nauk, In-t yazyikoznaniya.

Kubryakova, E. S. (2008). Chasti rechi v onomasiologicheskom osveschenii [Parts of speech in onomasiological illumination]. Moscow, Russia: Izd-vo LKI.

Lakoff, G. (1987). Women, fire and dangerous things. Chicago, IL: Chicago University Press.
Lakoff, G., \& Johnson, M. (1980). Metaphors we live by. Chicago, IL: University of Chicago Press.

Mann, T. (1960). Sobranie sochineniy v 10 tomah [Collected works in 10 volumes] (Vol. 9). Moscow, USSR: Hudozhestvennaya literatura.

Meletinskiy, E. M. (1976). Poetika mifa [The poetics of myth]. Moscow, USSR: Nauka.

Meletinskiy, E. M. (1998). Pervobyitnyie istoki slovesnogo iskusstva [Primitive origins of verbal art]. In Izbrannyie stati. Vospominaniya (pp. 52110). Moscow, Russia: Izd-vo RGGU, In-t vyisshih gumanitarnyih issledovaniy.

Nikitin,M.V.(1996).Kurs lingvisticheskoy semantiki [The course of linguistic semantics]. Saint-Petersburg, Russia: Nauchnyiy tsentr problem dialoga.

Nikitin, M. V. (2003). Osnovaniya kognitivnoy semantiki [The bases of cognitive semantics]. SaintPetersburg, Russia: Izd-vo RGPU im. A. I. Gertsena.

Onions, C. T. (1966). Oxford dictionary of English etymology. Oxford, UK: The Clarendon Press.

Podosinov, A. V. (1999). Orientatsiya po stranam sveta $v$ arhaicheskih kulturah Evrazii [Orientation to the cardinal in archaic cultures of Eurasia]. Moscow, Russia: Yazyiki russkoy kulturyi.

Porohnitskaya, L. V. (2014). Kontseptualnyie osnovaniya evfemii $v$ yazyike (na materiale angliyskogo, nemetskogo, frantsuzskogo, ispanskogo i italyanskogo yazyikov) [Conceptual foundations of euphemy in the language (based on English, German, French, Spanish and Italian)]. Moscow, Russia: MGLU.

Simpson, J. A., Weiner, E. S. C. (1989). Oxford English Dictionary (2nd ed.). Oxford, UK: The Clarendon Press.

Toporov, V. N. (1992). Zhivotnyie. Mifyi narodov mira [Animals. Folk tales from all over the world] (Vol. 1). Moscow, Russia: Sovetskaya entsiklopediya.

Vendler, Z. (1967). Linguistics in philosophy. Ithaca, NY: Cornell University Press.

Vezhbitskaya, A. (2011). Semanticheskie universalii $i$ bazisnyie kontseptyi [Semantic universals and basic concepts]. Mocow, Russia: Yazyiki slavyanskih kultur.

Zyikova, I. V. (2014). Rol kontseptosferyi kulturyi $v$ formirovanii frazeologizmov kak kulturno-yazyikovyih znakov [The role of culture in shaping the conceptual sphere of phraseology as a cultural-linguistic signs]. Moscow, Russia: Institut yazyikoznaniya RAN. 